\section{Equivocation on cooperation}

\section{Washington}

DesprTe President George Bush's election promises to take the lead in tackling global climate change, his administration has outraged the US Congress and environmental groups by hesitating over whether to send official representatives to an international environmental conference in the Domestic Policy Council finally agreed that the president's science adviser, Allan Bromley, should accompany Bill Reilly, the head of the Environmental Protection Agency, to the conference, but, it is said, has not allowed Reilly to invite participants to another conference that would be hosted by the United States next year. A new inter-agency working group set up to develop the administration's policy on global climate change will meet this week to decide whether to support the global climate convention that will be proposed at the Netherlands conference.

The controversy hijacked a hearing of the Senate Committee on Commerce, Science, and Transportation last week whose purpose was ostensibly to consider the nominations of James Wyngaarden, the former director of the National Institutes of Health, and Thomas Ratchford to be associate directors of the Office of Science and Technology Policy (OSTP). Bromley denied that the administration was opposed to negotiating a global climate convention, but emphasized that it would undertake no action until the end of 1990, when the Intergovernmental Panel on Climate Change (IPCC) will have completed its studies. Formed under the auspices of the United Nations Environment Programme and the World Meteorological Organisation, the IPCC is reviewing the scientific evidence for global warming, the social and economic impact of possible climate changes and ways of dealing with the problem.

Senator Albert Gore (Democrat, Tennessee) said he was "extremely disappointed" with the advice Bromley was giving to Bush on this issue after Bromley's refusal to say whether he had initially been opposed to attending the conference or whether he was in favour of negotiating a convention were interpreted as indicating his opposition to both. Although earlier this year Bush signed a declaration at the G-7 economic summit that "strongly advocates" common efforts to limit emissions of carbon dioxide and other greenhouse gases and declares that a global convention on climate change is "urgently required", Bromley said that there was a difference of opinion between the administration and Congress over the definition of 'urgent'. He also said that there was "a substantial distance to go yet" before an adequate understanding of Netherlands next week. The White House the science of global change would be reached, and quoted a recently revised that reduced the predicted temperature increase for a given addition of carbon dioxide from 5.2 to $1.9{ }^{\circ} \mathrm{C}$ after a more sophisticated treatment of cloud behaviour was added. Bromley also emphasized that discussion so far has focused too much on "the input side of the global change equation" and that more studies are needed of the economic consequences of a convention.

Eleven environmental groups, including the Natural Resources Defense Council, the Environmental Defense Fund and the National Audubon Society, offered Bush rather different advice last week on policies to tackle global warming. In a joint declaration, they called on Bush to support a 20 per cent reduction in national carbon-dioxide emissions by the year 2000 , an international convention to reduce emissions of greenhouse gases, and the development of a national climate policy. At a hearing of the House of Representatives subcommittee on human rights and international organizations, they all endorsed a bill to coordinate better federal research on climate change through the Committee on Earth Sciences of the OSTP.

Christine McGourty model from the UK Meteorological Office over contamination fears

\section{San Francisco}

BowING to growing community concern over toxic contamination, and citing changing business needs, the Rocketdyne Division of the Rockwell International Corporation has decided it will shut down a nuclear laboratory, used for processing radioactive materials, at its Santa Susana Field Laboratory east of Los Angeles.

The decision, announced on 20 October and due take effect exactly a year later, will close a 30-year-old operation. Making the announcement, the company said there had been a change in federal government emphasis away from the liquid-metal fastbreeder reactors, in which Rocketdyne had done specialized contract work, towards light-water reactors.

But Rockwell has also been suffering from revelations that a US Department of Energy survey had found radioactive and chemical contamination of the soil beneath the 2,600-acre Santa Susana site, although no immediate health hazard was declared.

Rocketdyne had originally requested a 10-year extension of its operating licence from the Nuclear Regulatory Commission (NRC), but has now asked for an extension only until 20 October 1990 to allow time for the company to complete its decontamination and decommissioning plan for the facility.

Robert Buderi

\section{Japan agrees to total ban on imports}

Tokyo

JAPAN, the world's largest importer of ivory, has at last agreed to a total ban on ivory imports, at least for the time being.

The Japanese cabinet decide on 20 October to abide by the ban on all imports implemented by the Convention on International Trade in Endangered Species (CITES) at a meeting in Lausanne, Switzerland, earlier in October. Japan at first joined South Africa, Zimbabwe and Botswana in opposing calls for a ban but then abstained at the final vote.

CITES member nations are concerned about rapidly dwindling elephant populations in Africa. But South Africa, Zimbabwe and Botswana claim that their elephant

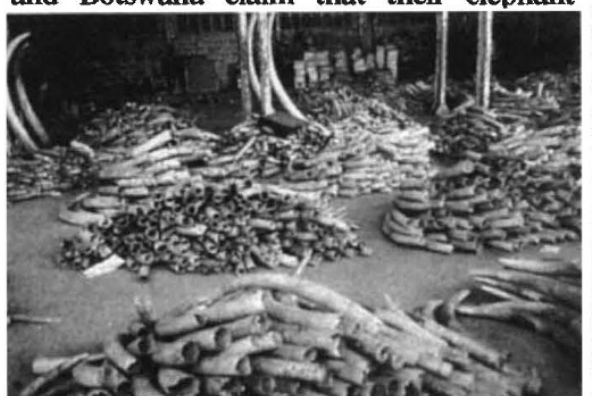

Tonnes of ivory confiscated from poachers in Africa populations are stable or increasing due to conservation measures and wish to continue their lucrative ivory trade.

In June, the Ministry of International Trade and Industry (MITI) imposed a ban on indirect ivory imports from suppliers in such places as Hong Kong and Singapore. But ivory importers immediately began to stockpile and MITI responded with a 'temporary' total ban in September (Nature

Japan's decision to abide by the CITES ruling, rather than filing a reservation to get around the ban as several African nations plan to do, may in part be due to the fact that Tokyo will host the next CITES meeting in 1991. If imports had continued, Japan would be in a very embarassing position.

But Cecilia Song of TRAFFIC Japan, the trade monitoring wing of the Worldwide Fund for Nature (WWF), says that MITI and the ivory industry hope to resume trade in the near future. The Lausanne agreement allows for resumption of trade after two years if countries can show they have developed an effective strategy to protect elephant populations.

In the meantime, Japan's ivory importers have begun importing mammoth tusks from the Soviet Union. 341, 270; 1989).
David Swinbanks 